\title{
Emergency Department Management Following the Sultanahmet Square Suicide Bombing in İstanbul: One Hospital's Experience
}

\author{
istanbul Sultanahmet Meydanı Bombalı Intihar Eylemi Sonrası Acil Servis \\ Yönetimi: Bir Hastanenin Deneyimi
}

\author{
Asım Kalkan, Özgür Söğüt \\ Haseki Training and Research Hospital, Clinic of Emergency Medicine, Istanbul, Turkey
}

\section{To the Editor,}

The number of suicide bombings is increasing worldwide. One such suicide bombing, in Sultanahmet Square, İstanbul, on January 12, 2016, killed 10 people and injured 14. Some of the injured were brought to the istanbul Haseki Training and Research Hospital, one of the hospitals closest to the scene of the explosion. Here, we describe our procedures and review what should happen before and after hospital arrival in the event of such tragedies. The bombing occurred at approximately 9:30 a.m. Ambulances, the fire service, and police teams reached the scene within 10 minutes. Neighboring hospitals, including the physician in charge of our emergency department, were alerted. Immediately after receiving news of the blast, our hospital orthopedics, general surgery, cardiovascular surgery, anesthesia, and ophthalmology specialists were ready and waiting in our emergency department. Patients already present in our emergency department who were in poor general condition were reassessed by internal medicine and anesthesia specialists and immediately placed in the intensive care unit. The outpatient door to the emergency department was closed, and outpatient admission was suspended. The emergency physicians serving in the emergency department were divided into six groups, and each was given an emergency medicine intern. Preparations were made in the red and yellow zones. During these preparations, gurneys were taken outside, each to an area in which at least two physicians could work on one patient. The equipment accompanying each gurney included oxygen cylinders and aspiration and intubation sets. Additional assistants and nurses were borrowed from other departments. The first patient reached our hospital at approximately 9:50 a.m.

The first of the three patients brought to our hospital was a 75-year-old man in cardiorespiratory arrest. Resuscitation had been started in the ambulance, and this was continued. The physical examination revealed burned hair and an approximately 2-cm wound in the left upper abdominal quadrant. When the patient was intubated, fluid and hemorrhagic foam emerged from the intubation tube. Resuscitation was continued for 30 minutes with no response. Bedsides, ultrasonography showed diffuse fluid present inside the abdomen. Terrorists generally use small metal fragments or nails to increase the effect of the blast during suicide bombings (1). We attributed our patient's abdominal injury to such shrapnel and suspected that the burnt hair was due to his close proximity to the blast. We attributed the hemorrhagic fluid from the lungs to the pressure effect occurring secondary to the explosion. In bombing attacks, the main cause of death is the overpressure that forms at the time of the explosion and the impact of bomb fragments (2).

Our second patient was a 60-year-old woman with a Glasgow coma score of 7. A heart beat was present, but her respirations were shallow, and she was intubated. The left eye was perforated. No wounds were found in the body, but her hair was also burned. Bedsides, ultrasonography was normal. Computed tomography
Address for Correspondence/Yazışma Adresi: Özgür Söğüt

Haseki Training and Research Hospital, Clinic of Emergency Medicine, İstanbul, Turkey Phone: +90 2123456743 E-mail: ozgur.sogut@hasekihastanesi.gov.tr

Received/Geliş Tarihi: 01 May 2016 Accepted/Kabul Tarihi: 01 June 2016 'Copyright 2016 by The Medical Bulletin of
Haseki Training and Research Hospital The Medical Bulletin of Haseki published by Galenos Yayınevi. ๑Telif Hakkı 2016 Haseki Eğitim ve Araştırma Hastanesi Haseki Tıp Bülteni, Galenos Yayınevi tarafından basılmışıı. 
of the brain revealed a subdural hematoma extending approximately $3 \mathrm{~cm}$ in the left parietal lobe. The patient was immediately taken for surgery. Postoperatively, treatment continued in the intensive care unit. Our third patient was a 35-year-old woman. Her general condition was good, and she was conscious. Physical examination revealed a tissue loss injury on the left thigh $3-4 \mathrm{~cm}$ in diameter. Otherwise, the systems examination and peripheral pulses were normal. Direct radiography revealed a metal foreign body in the proximal lateral thigh. She was hospitalized for monitoring. The metal object was removed, and the patient was discharged on the second day.

since it is impossible to determine how many people have been affected by a suicide bombing in the early stage, the initial hospital preparations must be thorough. Inter-hospital coordination of the ambulance dispatch system and the organized transport of equal numbers of patients to different hospitals will help reduce the burden on each emergency department. The presence of various surgical specialists and the rapid organization of red and yellow zone trauma rooms enabled us to react to our patients effectively. Injuries arising from the overpressure secondary to the explosion, from the penetration of metal bomb fragments, and burns must not be overlooked during patient examinations (3). We observed all three in our patients. With the increasing numbers of suicide bombings, we believe that emergency departments, especially those in large cities, must make thorough pre- and in-hospital preparations and that all emergency department personnel must receive regular training.

Keywords: Emergency department, management, suicide bombing, Sultanahmet square

Anahtar Sözcükler: Acil servis, yönetim, bombalı intihar, Sultanahmet meydanı

\section{Ethics}

Peer-review: Externally peer-reviewed.

\section{Authorship Contributions}

Concept: Özgür Söğüt. Design: Özgür Söğüt. Data Collection or Processing: Özgür Söğüt, Asım Kalkan. Analysis or Interpretation: Özgür Söğüt. Literature Search: Asım Kalkan. Writing: Asım Kalkan, Özgür Söğüt.

Conflict of Interest: No conflict of interest was declared by the authors.

Financial Disclosure: The authors declared that this study received no financial support.

\section{References}

1. Wightman JM, Gladish SL. Explosions and blast injuries. Med 2001; 37:664-78.

2. Katz E, Ofek B, Adler J, et al. Primary blast injury after a bomb explosion in a civilian bus. Ann Surg 1989;209:484-8.

3. Almogy $G$, Belzberg $H$, Mintz $Y$, et al. Suicide bombing attacks: update and modifications to the protocol. Ann Surg 2004;239:295-303. 